\title{
A Case of Squamous Cell Carcinoma of the Bilateral External Auditory Canals
}

\author{
Dong Won Jung and Sung-Wook Jeong \\ Department of Otolaryngology-Head and Neck Surgery, Dong-A University College of Medicine, Busan, Korea
}

\section{양측 외이도를 침범한 편평상피암 1 예}

정 동 원 · 정 성 욱

동아대학교 의과대학 이비인후-두경부외과학교실

\author{
Received March 31, 2017 \\ Revised June 28, 2017 \\ Accepted July 2, 2017 \\ Address for correspondence \\ Sung-Wook Jeong, MD, PhD \\ Department of Otolaryngology- \\ Head and Neck Surgery, \\ Dong-A University \\ College of Medicine, \\ 26 Daesingongwon-ro, Seo-gu, \\ Busan 49201, Korea \\ Tel $+82-51-240-5423$ \\ Fax $+82-51-253-0712$ \\ E-mail dau_su@naver.com
}

A malignant tumor of the external auditory canal (EAC) is a rare tumor, with a prevalence of between 1 and 6 people per 1 million population. Common symptoms of the EAC cancer include otorrhea, hearing loss, otalgia, or tinnitus, which are similar to symptoms of otitis media or otitis externa. Therefore, diagnosis may be delayed due to lack of EAC cancer-specific symptoms and the prognosis is also relatively poor despite intensive treatment. The most malignant tumor of the EAC is squamous cell carcinoma (SCC), which usully invades the ear unilaterally. SCC of bilateral EAC is extremely rare. We report here a rare case of bilateral EAC SCC. In this case, unilateral EAC SCC was treated via stereotactic radiosurgery and contralateral EAC SCC developed subsequently. This case implicates that radiosurgery can be a treatment option for EAC SCC but it may have carcinogenic effect. This case also shows that the ear should be examined bilaterally even when unilateral EAC cancer is encountered.

Korean J Otorhinolaryngol-Head Neck Surg 2019;62(1):64-8

Key Words Bilaterality · External auditory canal · Squamous cell carcinoma.

\section{서 론}

외이도 악성종양은 $1,000,000$ 명 중 약 1 6명에서 발생하는 비교적 드문 암으로 $80 \%$ 이상이 편평상피암이다. ${ }^{1)}$ 외이도 악 성종양은 중이염이나 외이도염과 동반되는 경우가 많고, 초기 증상이 이루, 이통, 청력감소와 같은 비특이적인 이과적 증상 이 많아 진단이 늦어질 수 있다. 또한 경동맥, 뇌정맥동, 뇌신 경, 경막 등 주요한 구조물에 근접하여 발생하고 침습성이 강 한 경향이 있어 적극적인 치료에도 불구하고 예후가 비교적 불 량하다. ${ }^{1,2)}$

외이도 악성종양의 가장 주요한 치료는 수술적 치료이다. 종양의 침범 범위에 따라 수술 부위를 결정하게 되며, 부분

This is an Open Access article distributed under the terms of the Creative Commons Attribution Non-Commercial License (https://creativecommons.org/licenses/by-nc/4.0) which permits unrestricted non-commercial use, distribution, and reproduction in any medium, provided the original work is properly cited.
외이도 절제술, 외측 측두골 부분절제술, 측두골 아전절제술, 측두골 전절제술 등을 시행할 수 있다. 술 후 방사선 치료는 치료 성적을 높이는 데 도움이 된다고 알려져 있다. 치료 후 에는 재발 여부 평가를 위한 추적관찰이 중요하며, 추적관찰 에는 신체검사, 자기공명영상 또는 전산화단층촬영, 양전자단 층촬영 등을 시행할 수 있다. 외이도 악성종양은 대부분 일측 성으로 발생하기 때문에 치료에 대한 반응과 치료 후 재발 여 부를 평가할 때 주로 동측 귀에 대한 진찰을 시행하게 된다.

저자들은 이루와 이통을 주소로 내원한 79세 남자 환자에 서 우측 외이도 악성종양을 진단하고 방사선 치료를 통해 완 전 관해를 유도 후 경과관찰 중에 반대측 귀에 추가로 발생 한 외이도 악성종양을 진단하고 치료하였다. 저자들이 경험한 양측성 외이도 악성종양은 해외에서 현재까지 약 6 편 정도의 논문이 발표되었고, ${ }^{3-7)}$ 국내에서는 아직 보고된 바 없는 드문 증례인 바, 이를 문헌고찰과 함께 보고하고자 한다. 


\section{증 례}

79세 남자 환자가 약 1년 전부터 발생한 우측 이루, 이통으 로 타 병원에서 지속적으로 치료를 받았으나 호전되지 않아, 본원으로 의뢰되었다. 고혈압, 당뇨, 뇌혈관 질환, 종양 등의 과 거력은 없었다.

이내시경검사에서 우측 고막 비후, 이루 및 외이도 종물 소 견을 관찰할 수 있었고(Fig. $1 \mathrm{~A})$, 좌측 고막과 외이도는 정상 소견이었다. 이에 우측 외이도 세균배양검사와 종물에 대한 조 직검사를 시행하였다. 우측 이루의 세균배양검사에서는 methicillin resistance coagulase-negative staphylococcus 가 동정 되었고, 우측 외이도 종물에 대한 병리조직검사에서는 케라 틴을 형성하고 있는 외이도 고분화 편평상피암이 진단되었다 (Fig. 1B). 병기 설정을 위해 측두골 전산화단층촬영과 내이 도 자기공명영상, 양전자 컴퓨터단층촬영을 시행하였다.

측두골 전산화단층촬영에서는 병변이 골부나 중이강을 침 범하지 않고 외이도에 국한되어 있었고, $\mathrm{T} 1$ 강조 자기공명영
상에서도 우측 외이도 상·후벽에 국한된 중등도 신호강도 증 가가 관찰되었다(Fig. $1 \mathrm{C}$ ). 양전자 컴퓨터단층촬영에서는 우측 외이도 부위의 과대사 소견이 관찰되었으며(Fig. 1D), 경부림 프절 전이와 원격 전이 소견은 보이지 않았다. 종양이 외이도 에만 국한되어 있고 골벽 침윤이나 원격 전이 소견이 관찰되 지 않아 병기는 T1N0M0로 진단하였다.

환자와 보호자에게 근치적 치료인 외측 측두골 부분절제술 을 권유하였고, 외이도 폐쇄로 인한 전음성 난청의 발생, 안면 신경 마비의 가능성 등에 대해 설명하였다. 환자와 보호자는 수술에 대한 상당한 부담감을 가졌고, 의료진에게 수술적 치 료 방법 외 다른 대체 가능한 치료법에 대해서 요청을 하였다. 이에 근치적 방사선 치료를 시행하기로 최종 결정하였다.

6주간에 걸쳐 총 35회, $7150 \mathrm{cGy}$ 의 정위적 방사선 치료를 시행하였다. 치료 종료 3 개월 후 이내시경 소견상 외이도 종물 은 사라졌고, 양전자단층촬영에서는 이전에 보였던 외이도의 과대사 소견이 사라져, 악성종양은 완전 관해를 이루었다(Fig. $1 \mathrm{E})$. 이후 2개월마다 이내시경검사를 시행하였고, 6개월마다
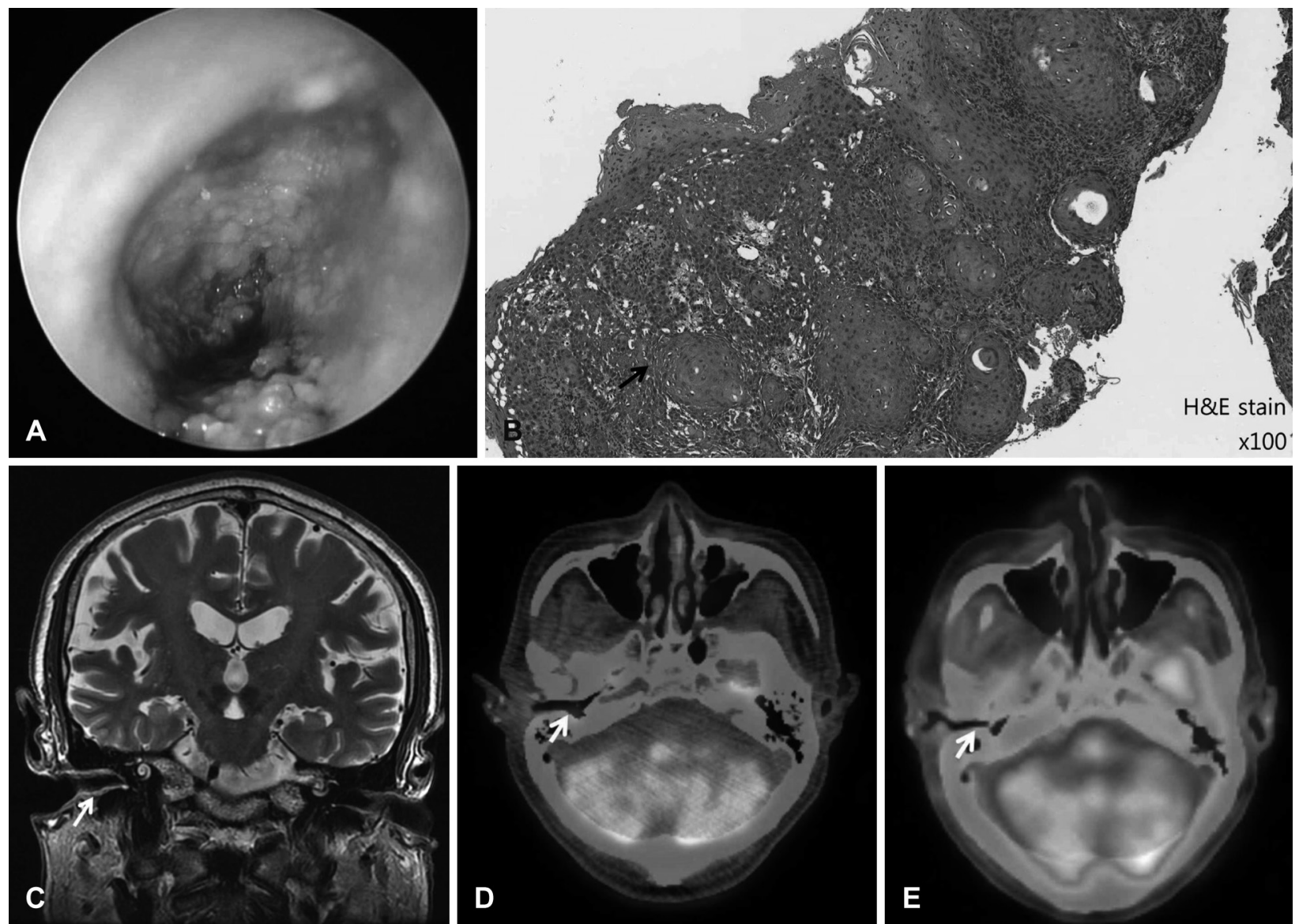

Fig. 1. The endoscopic, pathologic and imaging findings of right external auditory canal cancer. Endoscopic finding of right external auditory canal shows a circumferential polypoid mass lesion (A). Microscopic finding of biopsy specimen is compatible with well differentiated squamous cell carcinoma (arrow) (B). MRI image shows that the lesion (arrow) is confined to the ear canal without invasion to bony ear canal and middle ear (C). PET-CT scan reveals a hypermetabolic lesion (arrow) at right external auditory canal (D). Post radiotherapy PET-CT scan shows that a hypermetabolic lesion (arrow) at right external auditory canal disappears (E). 
내이도 자기공명영상을 촬영하였다. 1 년간 재발의 징후는 없 었다. 약 1 년 뒤 환자는 반대측 귀인 좌측 귀의 이루를 호소 하였다. 이내시경검사에서 좌측 외이도에 전반적인 미란성 염 증 소견과 부종, 폴립상의 종물 소견이 보였다(Fig. 2A). 외이 도염을 의심하고 좌측 외이도 세균배양검사를 시행하였고, methicillin sensitive kocuria kristinae가 동정되어 항생제 를 투여하였으나 호전이 없었으며, 통증과 외이도 피부 비후 및 폴립상의 종물이 지속되었다. 이에 종물에 대한 조직검사 를 시행하였으며, 우측 외이도암과 동일한 고분화 편평상피 암으로 진단되었다.

양전자단층촬영에서 이전 근치적 방사선 치료를 받았던 우 측 외이도에서는 과대사 소견이 보이지 않았고(Fig. 2B) 좌측 외이도에 국한된 과대사 소견을 보이는 새로운 병변이 관찰되 었으며(Fig. $2 \mathrm{C}$ ) 경부림프절 비대 및 원격 전이 소견은 보이지 않았다. 치료 방침 결정을 위해 혈액종양내과, 영상의학과, 병 리과와의 협진을 시행하였다. 과거 우측 외이도암이 외이도에 만 국한된 초기암이었고 주위 림프절의 침범과 원격 전이가 없었던 점으로 미루어 이번에 발생한 좌측 외이도암은 전이성 종양이 아닌 원발성 종양으로 판단하여 병기는 T1NOM0로 진
단하였다.

새로 발생한 좌측 외이도 악성종양에 대해 총 32회, $7120 \mathrm{cGy}$ 의 정위적 방사선 치료를 3개월에 걸쳐 시행하였다. 방사선 치 료와 더불어 이루 조절과 경과관찰을 위해 2주 간격으로 외 래 통원 치료를 병행하였고, 외이도 종물은 점진적으로 크기 가 감소하였다. 방사선 치료 종료 1 개월 뒤 환자는 좌측 측두 부의 극심한 두통을 호소하며 응급실로 내원하였고, 자기공 명영상 및 양전자단층촬영에서 원발 병소인 좌측 외이도의 병변은 모두 사라졌으나, 새로운 병변이 좌측 상고실로부터 추체골, 접형골, 유양동, 측두엽의 두개저, 뇌막 등을 광범위 하게 침범한 소견이 확인되었다(Fig. 3). 환자의 상태는 수술적 치료가 불가능한 상태로 혈액종양내과로 전과하여 동시적 항 암화학방사선 치료를 시행하였으며, 치료 중에 폐렴으로 사망 하였다.

\section{고 찰}

외이도에 발생하는 악성종양은 편평상피암이 가장 흔하고 기저세포암, 선암, 선양낭종암, 점액낭종암, 흑색종, 육종 등의
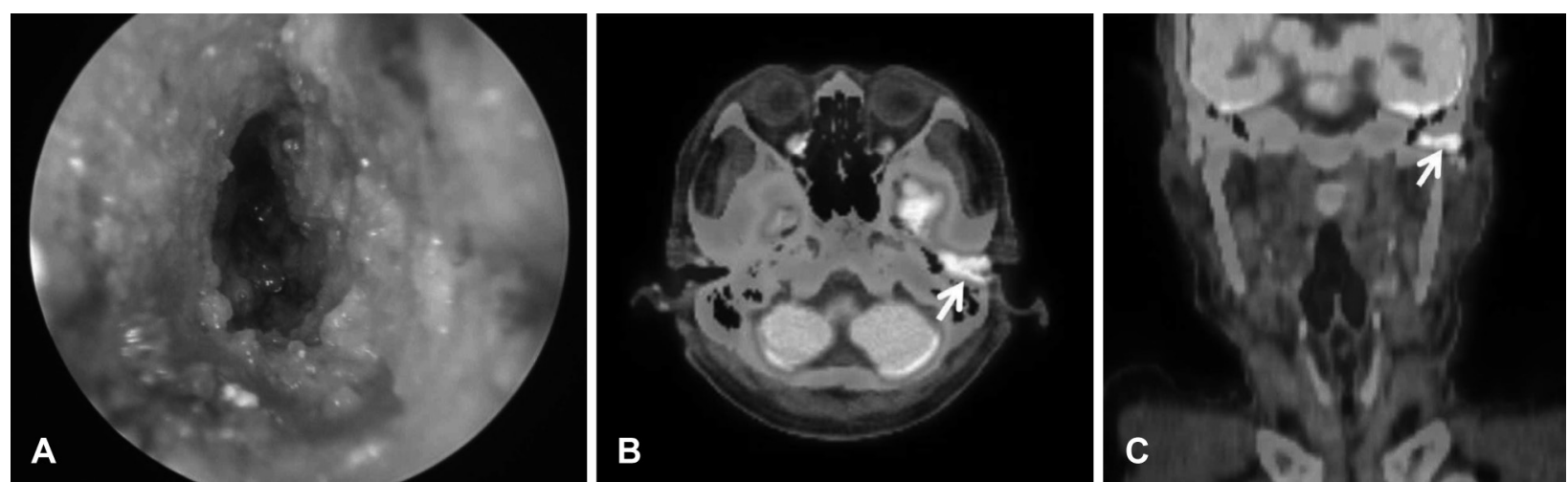

Fig. 2. The endoscopic and imaging findings of left external auditory canal cancer. Endoscopic finding of left external auditory canal shows a circumferential polypoid mass lesion (A). Axial (B) and coronal (C) sections of PET-CT reveals hypermetabolic lesions (arrows) at left external auditory canal.

Fig. 3. The imaging findings for left external auditory canal cancer after radiotheraphy. Axial (A) and coronal (B) images of PET-CT shows that primary lesion (arrowheads) of left external auditory canal disappears after radiotheraphy. But there are new hypermetabolic lesions at petrous apex, sphenoid, and left temporal lobe area (arrows), which are thought to be results of geographic failure of radiotheraphy.
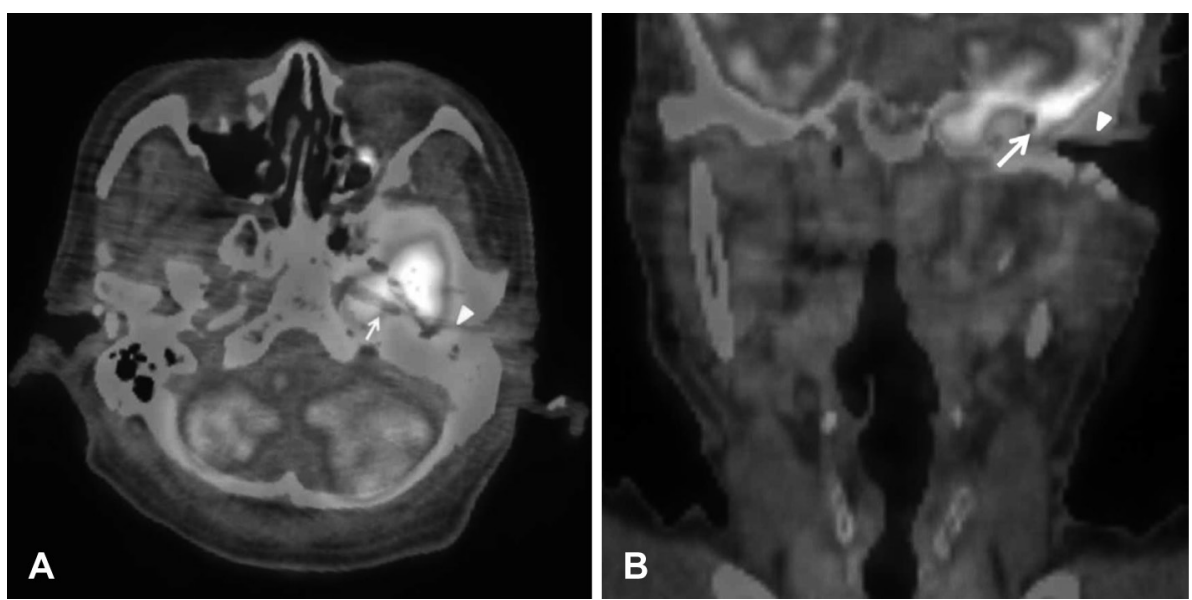
순서로 호발하는 것으로 보고되고 있으며, 편평상피암은 50 60 대에 호발하는 것으로 알려져 있다. ${ }^{8)}$ 발생원인은 명확히 밝 혀져 있지 않지만 자외선의 지속적 노출, 화학약품 등의 노출, 만성 화농성 중이염 등과 연관 가능성이 있으며 가장 주요한 원인은 이전의 방사선 치료 과거력이다. ${ }^{8)}$

외이도 악성종양은 대부분 원발암의 형태로 나타나며, 이루, 이통, 이명, 어지럼, 두통, 청력감소 등 비특이적 증상을 주로 유발하기 때문에 만성 중이염이나 외이도염으로 오인하기 쉬 워 조기 진단이 어려울 수 있다. 또한 외이도 악성종양은 인접 한 주위 구조물을 파괴시키면서 퍼져가는 공격적인 성향이 있어 예후가 비교적 불량하며, 외이도 림프가 Santorini fissure 를 통해 이동하면서 이하선으로 직접 전이될 수 있기 때문에, 외이도 악성종양 치료 시 이하선 절제술을 동시에 시행하기도 한다. ${ }^{9}$

외이도 악성종양의 치료는 종양의 일괴절제 후 방사선 치 료를 병행하는 것이 가장 좋은 결과를 나타낸다고 여러 연구 에서 보고하고 있다. ${ }^{9}$ 수술적 치료는 종양의 침범 범위에 따 라 결정되며, 부분 외이도 절제술, 외측 측두골 부분절제술, 측두골 아전절제술, 측두골 전절제술을 시행할 수 있다.

과거에는 외이도 악성종양에 대한 방사선 단독 치료가 시행 되기도 하였다. 1965년 Lederman ${ }^{10)}$ 은 방사선 단독 치료 환 자의 5년 생존율을 24\%로 보고하였고, 1988년 Mendenhall 등믄 방사선 단독 치료의 2년 생존율을 $80 \%$ 로 보고하였다. 그러나 이후 악성종양의 일괴절제를 위한 술기와 재건수술의 발전으로 방사선 치료는 수술의 보조적 치료로 시행되어 왔 으며, 외이도 악성종양에 대한 방사선 단독 치료는 수술적 치료가 불가능한 경우에 한해 고식적으로 시행되어 왔다. ${ }^{12)}$ 따라서 외이도 악성종양에 대한 방사선 단독 치료의 효과에 대한 보고는 많지 않으나, T병기 1기의 초기 외이도 악성종양 에서 근치적 방사선 치료 후 5년 생존율이 85 100\%로 보고 되고 있어 ${ }^{12}$ 초기암에서는 제한적으로 방사선 단독 치료법도 고려해 볼 수 있을 것으로 사료된다. 다수의 연구에서 $\mathrm{T} 2$ 병 기 이상인 경우에는 근치적 방사선 단독 치료를 권유하지 않 으며, 수술적 치료 이후 병행할 것을 권유하였다. ${ }^{12)}$ 본 증례는 종양이 외이도에 국한되어 있는 T1NOMO의 초기 양측성 외이 도 악성종양으로, 79 세의 고령인 점과 수술로 인한 전음성 난 청의 발생과 합병증 발생 가능성에 대한 부담으로 근치적 방 사선 치료를 시행하여, 원발 병소에 대한 완전 관해에는 성공 하였으나 종양 변연부의 잔존 병소의 진행으로 인해 최종적 으로 사망에 이른 증례이다.

원발성 두경부 악성종양에 대한 근치적 방사선 치료가 다른 두경부 영역에 새로운 악성종양을 유발할 가능성이 있다. 18 명의 외이도 악성종양 환자를 대상으로 한 연구에서, 7 명(39\%)
의 환자는 이전에 비인강암에 대한 방사선 치료를 받은 과거 력이 있는 것으로 조사되었다. ${ }^{13)}$ 또한 비인강암에 대한 근치적 방사선 치료 후 다른 두경부 영역에 방사선 유발 종양(radiation-induced tumor)이 발생할 확률이 0.04 7\%라고 보고된 바 있다. ${ }^{13)}$ 다른 연구에서는 두경부에 조사된 총 방사선량이 $5,500 \mathrm{cGy}$ 이상일 경우 이차적으로 육종이 발생할 가능성이 증가한다고 하였고, ${ }^{14)}$ 발생 시점은 방사선 치료 후 약 3 개월 20년에 걸쳐 다양하게 방사선 유발 종양이 나타난다고 보고 하였다. ${ }^{15)}$ 본 증례의 경우도 우측 외이도 악성종양에 대한 방 사선 치료 후 반대 측 외이도에 악성종양이 추가로 발생하였는 데, 최초 조사된 총 방사선량이 $5,500 \mathrm{cGy}$ 를 초과하는 7,150 $\mathrm{cGy}$ 였고, 그 후 약 1년이 경과한 후 반대 측 외이도에 악성종 양이 발생한 점은 두경부 방사선 조사 후 이차적 악성종양 발 생을 보고한 이전의 연구들에 부합한다고 할 수 있다. 비록 정위적 방사선 치료 기법을 사용하고 35 회에 걸친 분할 조사 를 시행하였음에도 불구하고 반대 측 외이도에 악성종양이 발생한 점을 고려할 때 외이도 악성종양에 대한 근치적 방사 선 치료를 시행할 경우 다른 부위로의 방사선 조사를 막기 위 한 차폐에 각별한 주의를 기울일 필요가 있다고 사료된다.

본 증례는 외이도 악성종양의 양측성 발생 가능성을 보여 주는 증례이다. 일측 외이도 악성종양의 치료를 완료한 후 경 과관찰을 시행할 때 반대 측 외이도에 대한 진찰도 함께 시행 할 필요가 있으며, 특히 근치적 방사선 치료를 시행한 경우에 는 반대측 외이도를 포함한 다른 두경부 영역의 종양 발생 가능성을 염두에 두고 면밀한 두경부 진찰을 시행할 필요가 있을 것으로 사료된다.

\section{REFERENCES}

1) Wolfe SG, Lai SY, Bigelow DC. Bilateral squamous cell carcinoma of the external auditory canals. Laryngoscope 2002;112(6):1003-5.

2) Moody SA, Hirsch BE, Myers EN. Squamous cell carcinoma of the external auditory canal: an evaluation of a staging system. Am J Otol 2000;21(4):582-8.

3) Elsürer C, Senkal HA, Zayyan E, Yilmaz T, Kaya S. Bilateral external auditory canal squamous cell carcinoma: a case report. Eur Arch Otorhinolaryngol 2007;264(8):941-5.

4) Thevarajah S, Carew J, Selesnick SH. Bilateral squamous cell carcinoma of the external auditory canal. Otolaryngol Head Neck Surg 2005;132 (6):960-2.

5) Munk-Nielsen L, Hansen HS. Bilateral carcinoma of the external auditory meatus. J Laryngol Otol 1991;105(2):112-4.

6) Fontanel JP, Klossek JM, Chauveau JM, Daban A, de Larrard J, Babin P. Epidermoid carcinoma of the external auditory canal. Rev Laryngol Otol Rhinol (Bord) 1989;110(1):13-5.

7) Hakata H, Ohashi T, Suzuki T. Bilateral carcinoma of the ears. Report of a case. Arch Otolaryngol 1976;102(2):112-4.

8) Lobo D, Llorente JL, Suárez C. Squamous cell carcinoma of the external auditory canal. Skull Base 2008;18(3):167-72.

9) Beyea JA, Moberly AC. Squamous cell carcinoma of the temporal bone. Otolaryngol Clin North Am 2015;48(2):281-92.

10) Lederman M. Malignant tumours of the ear. J Laryngol Otol 1965; 
79(2):85-119.

11) Mendenhall WM, Parsons JT, Amdur RJ, Cassisi NJ, Million RR. Squamous cell carcinoma of the head and neck treated with radiotherapy: does planned neck dissection reduce the change for successful surgical management of subsequent local recurrence? Head Neck Surg 1988;10(5):302-4.

12) Leong SC, Youssef A, Lesser TH. Squamous cell carcinoma of the temporal bone: outcomes of radical surgery and postoperative radiotherapy. Laryngoscope 2013;123(10):2442-8.
13) Abrigo JM, King AD, Leung SF, Vlantis AC, Wong JK, Tong MC, et al. MRI of radiation-induced tumors of the head and neck in postradiation nasopharyngeal carcinoma. Eur Radiol 2009;19(5):1197-205.

14) Patel SG, See AC, Williamson PA, Archer DJ, Evans PH. Radiation induced sarcoma of the head and neck. Head Neck 1999;21(4):346-54.

15) Zhu W, Hu F, Zhao T, Wang C, Tao Q. Clinical characteristics of radiation-induced sarcoma of the head and neck: review of 15 cases and 323 cases in the literature. J Oral Maxillofac Surg 2016;74(2): 283-91. 